\title{
Gender Differences and Themes in Peer Nominations for Chief Resident: a Qualitative Analysis
}

\author{
Maureen D. Lyons, $\mathrm{MD}^{7} \mathbb{1}$, Michelle K. Martinchek, MD, MPH${ }^{2}$, Patrick G. Lyons, $\mathrm{MD}^{3}$, \\ Justin R. Boike, MD, MPH' ${ }^{4}$, John F. McConville, MD², and Jeanne M. Farnan, MD, MHPE ${ }^{2}$ \\ 'Division of General Internal Medicine, St. Louis University School of Medicine, St. Louis, MO, USA; 2University of Chicago Medicine, Chicago, IL, USA; \\ ${ }^{3}$ Division of Pulmonary and Critical Care Medicine and the Department of Medicine, Washington University in St. Louis School of Medicine, St. Louis, \\ MO, USA; ${ }^{4}$ Division of Gastroenterology and Hepatology, Northwestern University Feinberg School of Medicine, Chicago, IL, USA.
}

J Gen Intern Med 34(12):2733-4

DOI: $10.1007 / \mathrm{s} 11606-019-05221-1$

(c) Society of General Internal Medicine 2019

\section{INTRODUCTION}

We sought to describe what qualities residents recognize in peers nominated for the Chief Resident (CR) position and whether particular attributes are valued differently in male and female nominees.

\section{METHODS}

We analyzed peer CR nominations from the University of Chicago Internal Medicine Residency Program for academic years 2013-2015. Nominations were solicited via email and nominators were encouraged to include qualitative comments. We used a constructivist paradigm and grounded theory approach to describe attributes noted for CR nomination and gender differences in those nomination comments. Nominator comments were reviewed using an iterative process and data were analyzed using a constant comparative method with no a priori hypotheses. Themes and sub-themes were generated and refined via discussion to develop a final coding strategy. Two investigators then coded the entire sample using this framework, resolving disagreements by discussion. Descriptive statistics were performed on the data related to gender and post-graduate year of the nominator. The University of Chicago IRB granted this project exemption. This study adheres to the criteria established by the Standards for Reporting Qualitative Research. ${ }^{1}$

\section{RESULTS}

A total of 365 residents ( $51 \%$ female, $49 \%$ male) were eligible to submit nominations and be nominated. Female residents represented $44 \%$ of the total nominators (126/288), while male residents represented $56 \%$ of all nominators (162/288). Of

Received April 24, 2019

Accepted July 12, 2019

Published online August 5, 2019 those female residents who chose to nominate a classmate for the chief resident role, $23 \%$ (29/126) were interns, $32 \%$ (40/126) were PGY-2, 42\% (53/126) were PGY-3, and 3\% (4/126) were PGY-4 Medicine-Pediatric residents. Of the 162 male nominators, $6 \%(9 / 162)$ were interns, $36 \%(59 / 162)$ were PGY-2, 57\% (93/162) were PGY-3 and $<1 \%(1 / 162)$ was a PGY-4 Medicine-Pediatrics resident.

Female residents received 136 (47\%) of 289 total nominations, with 87 (64\%) of these containing comments. Male residents received 153 (53\%) nominations; 93 (61\%) contained comments. Female nominators provided comments for male and female nominees at similar rates with $26 \%$ of female nominations and $24 \%$ of male nominations including comments. Similarly, male nominators provided comments at similar rates, including comments for $38 \%$ of female nominations and $37 \%$ of male nominations. Self-nominations were infrequent, with only $2 \%(3 / 136)$ of female and $3 \%(5 / 153)$ representing self-nomination.

Seven themes resulted from the iterative coding of the nomination comments. Under each theme, several subthemes were subsequently described (Table 1).

\section{DISCUSSION}

To our knowledge, this is the first study to describe a skill set that peers identify as important for the role of chief resident of an internal medicine residency program. Our data suggest that four of the Accreditation Council for Graduate Medical Education (ACGME) competencies ${ }^{2}$ - Interpersonal and Communication Skills, Patient Care, Medical Knowledge, and Professionalism - are most valued by peer nominators, irrespective of nominator or nominee gender.

Interestingly, our qualitative data suggests that nominators value the same qualities in both male and female CR candidates, and our quantitative analysis showed no significant differences in the rates of nominations by gender. The strikingly similar quantitative and qualitative findings are particularly illuminating in light of the existing leadership gender gap that is evident for women in academic medicine. Despite women comprising nearly half of medical school graduates since the early 1990s, gender inequity continues in academic 
Table 1 Themes and Sub-themes Generated for All Nominations

\begin{tabular}{|c|c|c|c|}
\hline Theme & Sub-theme & Representative quote(s) & Total mentions \\
\hline Interpersonal and Communication skills & $\begin{array}{l}\text { Enthusiasm } \\
\text { Humanism } \\
\text { Approachability } \\
\text { Confidence } \\
\text { Interpersonal relationships }\end{array}$ & $\begin{array}{l}\text { "always upbeat" } \\
\text { "positive attitude" } \\
\text { "integrity and thoughtfulness" } \\
\text { "easy to approach" } \\
\text { "confident and outspoken" } \\
\text { "easy to get along with... pleasure to be around" }\end{array}$ & 241 \\
\hline Patient Care & $\begin{array}{l}\text { Work ethic } \\
\text { Clinical ability } \\
\text { Coolness under pressure } \\
\text { Organization } \\
\text { Team management }\end{array}$ & $\begin{array}{l}\text { "assists colleagues when needed" } \\
\text { "always goes the extra mile" } \\
\text { "strong clinically" } \\
\text { "amazing doctor" } \\
\text { "composure in...chaos" } \\
\text { "organized and efficient" } \\
\text { "runs her team very well and creates a fun, } \\
\text { collaborative environment" }\end{array}$ & 171 \\
\hline Medical Knowledge & $\begin{array}{l}\text { Teaching and learning } \\
\text { Fund of knowledge }\end{array}$ & $\begin{array}{l}\text { "motivated as a teacher and a learner" } \\
\text { "incredibly smart" }\end{array}$ & 145 \\
\hline Professionalism & $\begin{array}{l}\text { Well-respected } \\
\text { Leadership } \\
\text { Role model }\end{array}$ & $\begin{array}{l}\text { "universally respected by her peers" } \\
\text { "a natural leader" } \\
\text { "valuable role model for other residents" }\end{array}$ & 116 \\
\hline Administrative Ability & $\begin{array}{l}\text { Program advocacy } \\
\text { Ability work with administration }\end{array}$ & $\begin{array}{l}\text { "great advocate for the program } \\
\text { "would work well with administration and staff to } \\
\text { make good lasting changes for us" }\end{array}$ & 44 \\
\hline Special Attributes & $\begin{array}{l}\text { Research experience } \\
\text { Career plans } \\
\text { Partner factors } \\
\text { Personality traits } \\
\text { Technical skills }\end{array}$ & $\begin{array}{l}\text { "lots of research experience" } \\
\text { "committed to academia" } \\
\text { "plans to go into General Internal Medicine" } \\
\text { "[she's] married to [him] and it would be cute if they } \\
\text { were chiefs together" } \\
\text { "problem-solver" } \\
\text { "asset because of skill with iPads" }\end{array}$ & 37 \\
\hline Concerns & $\begin{array}{l}\text { Personality traits } \\
\text { Job characteristics }\end{array}$ & $\begin{array}{l}\text { "can be a bit reserved" } \\
\text { "is not super extroverted" } \\
\text { "may not like bureaucracy" }\end{array}$ & 9 \\
\hline
\end{tabular}

medicine, with evidence suggesting that disproportionately fewer women fill leadership positions ${ }^{3}$ and achieve senior academic ranks. ${ }^{4}$ From this perspective, our findings may offer some hope that the current generation of physicians in training may be on track to disrupt this status quo.

In conclusion, our data describe a peer-determined skill set valued as important in the role of Chief Resident, and highlight four ACGME competencies: Medical Knowledge, Patient Care, Communication, and Professionalism. Our qualitative data and quantitative data are similar between genders, demonstrating a similar value of specific qualities regardless of the gender of the nominator or nominee. These findings may have important implications for selection of Internal Medicine Chief Residents in the future and for female trainees in internal medicine aspiring to leadership roles.

Corresponding Author: Maureen D. Lyons, MD; Division of General Internal Medicine St. Louis University School of Medicine, St. Louis, MO, USA (e-mail: maureen.lyons@health.slu.edu).

\section{Compliance with Ethical Standards:}

Conflict of Interest: The authors declare that they do not have a conflict of interest.

\section{REFERENCES}

1. O'Brien BC, Harris IB, Beckman TJ, Reed DA, Cook DA. Standards for reporting qualitative research: a synthesis of recommendations. Acad Med. 2014;89(9): 1245-51.

2. Milestones Guidebook - ACGME. Available at: https://www.acgme.org/ Portals/0/MilestonesGuidebook.pdf. Accessed September 5, 2018.

3. Rochon PA, Davidoff F, Levinson $\mathbf{W}$. Women in academic medicine leadership: has anything changed in 25 years? Acad Med. 2016; 91(8):1053-1056. https://doi.org/10.1097/ACM.0000000000001281.

4. The State of Women in Academic Medicine - AAMC. Available at https:// m e m b e r s . a a m c. org / e w e b / u p l o a d / The $\% 20$ State $\% 20$ of $\% 20$ Women $\% 20$ in $\% 20$ Academic $\% 20$ Medicine\%202013-2014\%20FINAL.pdf. Accessed September 5, 2018.

Publisher's Note Springer Nature remains neutral with regard to jurisdictional claims in published maps and institutional affiliations. 